$\mathbf{R}$

$\mathbf{O}$

\begin{abstract}
$\mathbf{Z}$
\end{abstract}
$\mathbf{P}$

$\mathbf{R}$

A

Studia Źródłoznawcze, t. LV

p-ISSN 0081-7147

e-ISSN 2451-1331

\title{
Kilka uwag o dwóch opowieściach o zwycięstwie Longobardów nad Herulami (Paweł Diakon, Historia Langobardorum, I, 20 i Prokopiusz z Cezarei, De Bellis, VI, 14)*
}

Zarys treści: Artykuł stanowi analizę fabuł dwóch opowieści o wojnie Longobardów z Herulami, przekazanych przez Prokopiusza z Cezarei i Pawła Diakona.

Abstract: The article presents an analysis of two narratives of the war between the Lombards and Heruls by Procopius of Caesarea and Paul the Deacon.

Słowa kluczowe: Herulowie, Longobardowie, Paweł Diakon, Prokopiusz z Cezarei, narracja, tchórzostwo, buta, pokora

Keywords: Heruli, Longobards, Paul the Deacon, Procopius of Caesarea, narrative, cowardice, arrogance, humility

\section{Wprowadzenie}

Herulowie z pewnością nie należą do tych barbarzyńskich ludów, którym przeznaczone było utworzyć silne i trwające kilka pokoleń królestwo na terenach należących ongiś do zachodniej części Cesarstwa Rzymskiego. Odoaker - o którym jedno źródło mówi, że został ustanowiony królem przez stacjonujących na terenie Italii Herulów ${ }^{1}$ - po abdykacji zachodniorzymskiego cesarza Romulusa Augustulusa władał Italią, ale już w 493 r. został zdradziecko zamordowany przez ostrogockiego króla Teodoryka Wielkiego ${ }^{2}$. Herulowie, którzy stanowili elitarne oddziały wieloetnicznej armii Odoakra, zostali ponoć przez Ostrogotów wybici do nogi wraz ze swymi rodzinami ${ }^{3}$. Jednak Paweł Diakon donosi ${ }^{4}$, że pewien

* Niniejszy szkic dedykowany jest Profesorom Zbigniewowi Dalewskiemu (Instytut Historii PAN w Warszawie) i Piotrowi S. Góreckiemu (University of California Riverside). Moje najserdeczniejsze podziękowania zechcą również przyjąć: Pani Profesor Janet L. Nelson (King's College London), Panowie Profesorowie Jacek Banaszkiewicz (Instytut Historii PAN w Warszawie), Ian N. Wood (University of Leeds) oraz Bruce Lincoln (Divinity School of the University of Chicago). Bez udostępnionych przez nich prac nie byłoby możliwe podjęcie niniejszego tematu. Wszystkie tłumaczenia $\mathrm{z}$ łaciny pochodzą od Autora niniejszego tekstu.

1 Auctarium Havniense Ordo Prior, wyd. Th. Mommsen, w: MGH, Auctores Antiquissimi, t. 9, Berolini 1892, s.a. 476, s. 309; zob. też komentarz: W. Goffart, Barbarian Tides. The Migration Age and the Later Roman Empire, Philadelphia 2006, s. 207.

${ }^{2}$ Na temat tych wydarzeń zob. W. Ensslin, Theoderich der Grosse, München 1959, s. 62-73; J. Moorhead, Theoderic in Italy, Oxford 1992, s. 17-31; H. Wolfram, Die Goten. Von den Anfängen bis zur Mitte des sechsten Jahrhunderts. Entwurf einer historischen Ethnographie, München 2009, s. 281-284.

3 Anonymi Valesiani pars posterior, wyd. Th. Mommsen, w: MGH, Auctores Antiquissimi, t. 9, Berolini 1892, cap. 56, s. 320.

${ }^{4}$ Pauli Historia Langobardorum, wyd. L. Bethmann, G. Waitz, w: MGH, Scriptores rerum Langobardicarum et Italicarum, Hannoverae 1878, II, cap. 3, s. 73 [dalej: Paweł Diakon, Historia Langobardorum]. Istnieje polski przekład dwóch dzieł 
rex Brentorum o imieniu Sinduald (lub Sindual) ${ }^{5}$ - który w czasie wojen z Ostrogotami walczył pod cesarskim wodzem Narsesem - pochodził od Herulów, którzy przybyli do Italii wraz z Odoakrem, co stawia pod znakiem zapytania, czy faktycznie wojownicy Teodoryka wymordowali całą herulską populację na terenie italskiego królestwa ${ }^{6}$. Inna grupa Herulów, której siedziby mieściły się na północ od Dunaju, również nie miała wiele szczęścia ${ }^{7}$. Około $508 \mathrm{r}$. herulscy wojownicy pod wodzą króla Rodulfa stoczyli z innym barbarzyńskim ludem, Longobardami, bitwę, która zakończyła się ich sromotną klęską ${ }^{8}$. Właśnie ona jest obiektem analizy zaprezentowanej w niniejszych rozważaniach.

O szczegółach konfliktu Longobardów z Herulami relacjonują dwa źródła. Pierwszym z nich jest dzieło Prokopiusza z Cezarei De Bellis, które ukończone zostało w latach 50. VI w. ${ }^{9}$, drugim - Historia Langobardorum pióra Pawła Diakona, ukończona ok. 796 r. ${ }^{10}$ Przekazane przez obu dziejopisów relacje były już obiektem komentarzy historyków ${ }^{11}$. Dokonując choćby tylko pobieżnego porównania przekazów obu dzieł, stwierdzimy, że opisy przebiegu wojny mają ze sobą kilka punktów wspólnych - najważniejszym z nich jest to, że zarówno Prokopiusz, jak i Paweł Diakon przypisują zwycięstwo Longobardów interwencji Boga ${ }^{12}$. Longobardzki dziejopis ogólnie był zdania, że zwycięstwa odnoszone były nie dzięki odwadze mężów i wprawie w posługiwaniu się orężem, lecz dzięki łasce niebios - jak pisał: „Ponieważ zwycięstwo nie jest przyznane sile ludzi, lecz raczej z nieba jest dane”"13. Zresztą nie

dziejopisa Longobardów: Paweł Diakon, Historia rzymska, Historia Longobardów, tłum., wstęp i kom. I. Lewandowski, Warszawa 1995.

${ }^{5}$ Na temat Sindualda zob. J.R. Martindale, The Prosopography of the Later Roman Empire, t. 3B: A.D. 527-641, Cambridge 1992, s. 1154 n., s.v. Sindual.

${ }^{6}$ Powątpiewa w wartość tego fragmentu Anonymus Valesianus; J. Moorhead, Theoderic in Italy, s. 26 n.

7 Na temat Herulów zob. B. Rubin, Das Zeitalter Iustinians, t. 2, Berlin-New York 1995, s. 141-143; G. Neumann, M. Taylor, Heruler, w: Reallexikon der germanischen Altertumskunde, t. 14, Berlin-New York 1999, s. 468-474; W. Goffart, Barbarian Tides, s. 205-210; W. Pohl, Die Völkerwanderung. Eroberung und Integration, Stuttgart 2002, s. 122 n.; R. Steinacher, The Herules. Fragments of a History, w: Neglected Barbarians, red. F. Curta, Turnhout 2010, s. 321-364; A. Sarantis, The Justinianic Heruli. From Allied Barbarians to Roman Provincials, w: tamże, s. 361-402.

${ }^{8} \mathrm{Na}$ temat Rodulfa zob. C. Krag, Rodulf, w: Reallexikon der germanischen Altertumskunde, t. 25, Berlin-New York 2003, s. 58; A.S. Christensen, Cassiodorus, Jordanes and the History of the Goths. Studies in a Migration Myth, Copenhagen 2002, s. 270, 293. Na temat tych wydarzeń zob. W. Pohl, Die Gepiden und die Gentes an der mittleren Donau nach dem Zerfall des Attilareiches, w: Die Völker an der mittleren und unteren Donau im fünften und sechsten Jahrhundert, red. H. Wolfram, F. Daim, Wien 1980, s. 239-305, zwł. s. 277-278; tenże, Die Awaren. Ein Steppenvolk in Mitteleuropa 567-822 n. Chr., München 1988, s. 54-55.

9 Procopius, De Bellis, 6, 14, 10-22, wyd. i thum. H.B. Dewing, w: Procopius, History of the Wars, t. 3, London 1953-1954, s. 405-409 [dalej: Prokopiusz De Bellis]. Polski przekład dzieła Prokopiusza, w t. 2 przetłumaczono fragment o wojnie Herulów z Longobardami: Prokopiusz z Cezarei, Historia wojen, t. 2: Wojna z Gotami, wstęp, thum. i kom. D. Brodka, Kraków 2015, s. 150 n. Na temat Prokopiusza i jego dzieła zob. A. Cameron, Procopius and the Sixth Century, Berkeley-Los Angeles 1985; A. Kaldellis, Procopius of Caesarea. Tyranny, History, and Philosophy at the End of Antiquity, Philadelphia 2004; tenże, Introduction, w: Prokopios, The Wars of Justinian, thum. H.B. Dewing, A. Kaldellis, Indianapolis 2014, s. VII-XI.

${ }^{10}$ Na temat Pawła Diakona i jego dzieła zob. R. McKitterick, Paul the Deacon's Historia Langobardorum and the Franks, w: taż, History and Memory in the Carolingian World, Cambridge-New York 2004, s. 60-83; A. Plassmann, Origo gentis. Identitäts- und Legimitätsstiftung in früh- und hochmittelalterlichen Herkunftserzählungen, Berlin 2006, s. 191-242; F. Hartmann, Vitam litteris ni emam, nihil est, quod tribuam. Paulus Diaconus zwischen Langobarden und Franken, „Frühmittelalterliche Studien”, 43, 2009, s. 71-93.

${ }^{11}$ Poza pracami cytowanymi niżej zob.: O. Gschwantler, Die Heldensage von Alboin und Rosimund, w: Festgabe für Otto Höfler zum 75. Geburtstag, t. 3, red. H. Birkhan, Wien-Stuttgart 1976, s. 214-254; S. Müller, Als die Bilder laufen lernten. Über die Erzählung vom Untergang der Heruler bei Paulus Diaconus und die Möglichkeiten literarischer Rede in der höfischen Kultur des Mittelalters, w: Kunst der Bewegung. Kinästhetische Wahrnehmung und Probehandeln in virtuellen Welten, red. Ch. Lechtermann, C. Morsch, Bern 2004, s. 91-101.

12 J. Banaszkiewicz, Rodulf, król Herulów, który grał (Paweł Diakon, Hist. Long., I, 20), w: E scientia et amicitia. Studia poświęcone profesorowi Edwardowi Potkowskiemu w sześćdziesięciopięciolecie urodzin i czterdziestolecie pracy naukowej, red. M. Drzewiecki, Warszawa-Pułtusk 1999, s. 23.

${ }_{13}$ Paweł Diakon, Historia Langobardorum, I, cap. 8, s. 52: „Victoria enim non potestati est adtributa hominum, sed de caelo potius ministratur”. Na temat fabuł o bohaterach w narracji Pawła Diakona zob. W. Haubrichs, Die 'Erzählung des Helden' in narrativen Passagen der Historia Langobardorum des Paulus Diaconus, w: Narration and Hero. Recounting the Deeds of Heroes in Literature and Art of the Early Medieval Period, red. V. Millet, H. Sahm, Berlin-Boston 2014, s. 278-304; 
tylko on twierdził, że wiktoria na polu walki jest wynikiem interwencji siły wyższej. Żywiona przez chrześcijan we wczesnym średniowieczu wiara w to, że to Bóg w niebiosach rozstrzyga o losach bitew, zasługuje na osobne potraktowanie ${ }^{14}$. Tutaj interesuje mnie tylko, w jaki sposób dwaj wyżej wzmiankowani autorzy powiązali tę wiarę z losami wojny longobardzko-herulskiej. Zaprezentowane przez nich opowieści można potraktować jako fabuły - a więc jako układy zdarzeń pozostających w określonych związkach z innymi wydarzeniami oraz nadrzędną całością, którą one tworzą ${ }^{15}$. Zdarzenia zaś powiązane są ze sobą trzema relacjami, z których najważniejsza jest - dla niniejszych rozważań - relacja przyczynowo-skutkowa. Interesuje mnie, jak poszczególne zdarzenia w obu fabułach wpływają na siebie oraz to, w jaki sposób zdarzenia podporządkowane są głównemu przesłaniu, którym jest twierdzenie, że zwycięstwo dane jest z nieba, czyli zależne jest od woli Najwyższego.

Bogactwo obydwu opowieści, które okraszone są różnymi ciekawymi motywami, wartką akcją i wspaniale pomyślanymi związkami przyczynowo-skutkowymi między poszczególnymi zdarzeniami, każe przyjrzeć się im bliżej ${ }^{16}$. W wersji Prokopiusza oba ludy - zarówno Longobardowie, jak i Herulowie - są równorzędnymi bohaterami opowieści. Jedni przedstawieni są jako ci, którzy robią wszystko, aby nie dopuścić do wybuchu konfliktu zbrojnego, drudzy zaś opisani jako główni prowodyrzy wojny, nieubłagani w swym dążeniu do rozlewu krwi. W narracji Pawła Diakona zaś to Longobardowie wywołują wojnę i zwyciężają, ale głównymi postaciami w opowieści o bitwie są Herulowie, ich król Rodulf oraz niewymieniony z imienia umyślny, który z wysokości drzewa obserwował przebieg boju między dwoma ludami ${ }^{17}$. W analizie pokażę, w jak mistrzowski sposób wschodniorzymski dziejopis zademonstrował swoim czytelnikom, że zwycięstwo Longobardowie osiągnęli nie ot tak sobie, lecz dzięki temu, że na nie w oczach Ojca Niebieskiego zasłużyli. Wskaże, że w zaprezentowanej przez niego opowieści zachodzi relacja przyczynowo-skutkowa między pokorą i sprawiedliwością Longobardów a wyrokiem Boga, który nagrodził ich zwycięstwem. W analizie opowieści zaprezentowanej przez Pawła Diakona zademonstruję, w jaki sposób autor powiązał herulską butę z gniewem Najwyższego, który pokarał klęską lud dotąd wydający się niezwyciężonym ${ }^{18}$.

\section{Wojna Herulów z Longobardami - wersja Prokopiusza z Cezarei}

Prokopiusz relacjonuje, że Herulowie, gdy tylko stali się silniejsi i liczniejsi od wszystkich innych sąsiednich barbarzyńców, zaatakowali i pokonali wszystkie okoliczne ludy. W końcu uczynili Longo-

B.K. Vollmann, Paulus Diaconus und das Heldenlied, w: Impulse und Resonanzen. Tübinger mediävistische Beiträge zum 80. Geburtstag von Walter Haug, red. G. Vollmann-Profe i in., Tübingen 2007, s. 45-56; W. Haug, Die Grausamkeit der Heldensage. Neue gattungstheoretische Überlegungen zur heroischen Dichtung, w: Studien zum Altgermanischen. Festschrift für Heinrich Beck, red. H. Uecker, Berlin-New York 1994, s. 303-326.

${ }^{14}$ Zob. K. DeVries, God and Defeat in Medieval Warfare. Some Preliminary Thoughts, w: The Circle of War in the Middle Ages. Essays on Medieval Military and Naval History, red. D.J. Kagay, L.J.A. Villalon, Woodbridge 1999, s. 87-97; W. Goffart, Conspicuously Absent. Martial Heroism in the Histories of Gregory of Tours and its Likes, w: tenże, Barbarians, Maps, and Historiography. Studies on the Early Medieval West, Farnham-Burlington 2009, s. 95-120, 316 n.; J.-P. Bodmer, Der Krieger der Merowingerzeit und seine Welt. Eine Studie über Kriegertum als Form der menschlichen Existenz im Frühmittelalter, Zürich 1958; Ph. Wynn, Wars and Warriors in Gregory of Tours' Histories I-IV, „Francia”, 21, 2001, nr 1, s. 1-35; G. Halsall, Warfare and Society in the Barbarian West, 450-900, London-New York 2003; P. Żmudzki, Władca $i$ wojownicy. Narracje o wodzach, drużynie $i$ wojnach w najdawniejszej historiografii Polski i Rusi, Wrocław 2009; L. Sarti, Perceiving War and the Military in Early Christian Gaul (ca. 400-700 A.D.), Leiden-Boston 2013, zwł. s. 294-307; R. Stone, Morality and Masculinity in the Carolingian Empire, Cambridge 2012.

${ }^{15}$ Inspirujące były tutaj dla mnie rozważania: N. Frye, Myth, Fiction, and Displacement, w: tenże, Fables of Identity. Studies in Poetic Mythology, New York 1963, s. 21-39.

${ }^{16}$ Najlepszym instrumentem do analizy konstrukcji fabularnych jest oczywiście metoda porównawcza, którą próbowałem w niniejszym szkicu zastosować.

17 Por. O. Gschwantler, Formen langobardischer mündlicher Überlieferung, „Jahrbuch für internationale Germanistik”, 11, 1979, nr 1, s. 63.

18 Por. komentarz: tamże, s. 62. 
bardów - którzy byli już wtedy, jak twierdzi Prokopiusz, chrześcijanami ${ }^{19}$ - i kilka innych ludów trybutariuszami. Prokopiusz zaznacza, że Herulami w ich wojowniczych zapędach kierowała miłość do pieniędzy i arogancja ${ }^{20}$. Kiedy cesarz Anastazjusz objął tron we wschodniej części Imperium Rzymskiego, nie mieli oni już nikogo na świecie, kogo mogliby zaatakować, więc odłożyli oręż i pozostawali przez trzy lata w spokoju. Gdy okres ten minął, znów poczuli potrzebę toczenia wojny ${ }^{21}$. Celem ich ataku stali się Longobardowie. Chcąc wyruszyć w pole przeciwko nim, Herulowie - okrutnie sfrustrowani okresem pokoju i bezczynności - zaczęli bez opamiętania obrażać swego przywódcę Rodulfa. Napastując go wciąż, zarzucali mu tchórzostwo i zniewieściałość. Wyszydzali w najpodlejszy sposób i znieważali, wyzywając go od najgorszych, aż Rodulf, nie mogąc znieść spadających nań zniewag, postanowił ruszyć przeciw Longobardom.

Herulowie są „,czarnymi charakterami” opowieści, ich arogancja i żądza złota to niejedyne przywary, które ciążą na tym nad wyraz dzikim i barbarzyńskim ludzie ${ }^{22}$. Chcąc ruszyć na wojnę przeciwko Longobardom, posuwają się nawet do prowokowania własnego władcy. Brak szacunku dla własnego króla jest częścią obrazu niegodziwej natury Herulów zawartego w dziele Prokopiusza. Oskarżanie własnego władcy o zniewieściałość i tchórzostwo to na pierwszy rzut oka w gruncie rzeczy niewielkie przewiny, jeśli tylko spojrzeć na to, czego dopuszczali się oni wobec własnych monarchów. W ileś lat po wojnie z Longobardami Herulowie objawili w pełni swoją „,bestialską naturę”, zwracając się przeciw własnemu władcy Ochusowi i zabili go bez wyraźnego powodu - po prostu postanowili żyć bez króla ${ }^{23}$. W oczach tego ludu monarcha - mimo że nosił tytuł królewski - nie miał żadnej przewagi nad zwykłym Herulem. Świadczyły o tym również ich obyczaje - każdy miał prawo siedzieć z władcą przy stole i z nim ucztować, mógł też obrażać go bez opamiętania. Prokopiusz twierdzi, że nie ma na świecie innych ludzi, którzy byliby mniej związani obyczajami i bardziej niestali niż Herulowie. Objawiło się to w pełnej krasie, kiedy pozbawili Ochusa życia, a dokonali tego - jak wiemy - tylko z tego powodu, że pragnęli żyć bez króla ${ }^{24}$. Dokonawszy bestialskiego czynu, znów zmienili zdanie i skruszeni, stwierdzili tym razem, że jednak nie mogą żyć bez władcy i bez wodza. Prokopiusz jeszcze raz podkreśla niegodziwą naturę tego ludu, kiedy pisze, że u Herulów mężczyźni kopulują z osłami, co pokazuje, że grzech przeciwko naturze, polegający na spółkowaniu ze zwierzętami, jest u nich powszechny ${ }^{25}$. Prokopiusz bez ogródek pisał, że byli oni najpodlejszymi z ludzi i najniegodziwszymi łajdakami.

19 Odnośnie do kwestii, czy Longobardowie byli w V-VI w. arianami, zob. S.C. Fanning, Lombard Arianism Reconsidered, „Speculum”, 56, 1981, nr 2, s. 241-258, zwł. s. 247 n.; ponadto zob. J.T. Hallenbeck, Pavia and Rome. The Lombard Monarchy and the Papacy in the Eight Century, Philadelphia 1982, s. 13-15; przegląd dyskusji zob. P. Majocchi, Arrianorum abolevit heresem. The Lombards and the Ghost of Arianism, w: Arianism. Roman Heresy and Barbarian Creed, red. G.M. Berndt, R. Steinacher, Farnham-Burlington 2014, s. 231-238. Luźną spekulacją z mojej strony będzie twierdzenie, że to presja struktury narracyjnej kazała Prokopiuszowi uczynić wszystkich Longobardów katolikami już w czasie ich wojny z Herulami. O tym, że dla Prokopiusza chrześcijanie to w tym przypadku wyłącznie katolicy zob. S.C. Fanning, Lombard Arianism, s. 247-248.

${ }^{20}$ Por. komentarz: W. Pohl, Die Gepiden, s. 278. Według W. Pohla opowieść o wojnie Herulów z Longobardami jest odzwierciedleniem psychologii i ekonomii społeczeństwa barbarzyńskich wojowników oraz problemów występującej u nich monarchii - królestwa wojskowego (das Heerkönigtum). Badacz ten nie zadaje sobie trudu, aby dostrzec fabularną warstwę opowieści i jej ideową wymowę.

21 Już dawno zauważono chronologiczne problemy opowieści o wojnie Herulów z Longobardami u Prokopiusza. Jeśli miała ona wybuchnąc trzy lata po wstąpieniu Anastazjusza na cesarski tron (jak chce wschodniorzymski dziejopis), to bitwa stoczona zostać musiała w 494 r.; zob. C. Krag, Rodulf, s. 58. Zostawmy poza nawiasem rozważań spekulacje łączące Rodulfa z Hrólfem kraki.

${ }^{22} \mathrm{O}$ żądzy złota jako toposie charakteryzującym dzikie i barbarzyńskie ludy w dziełach antycznych i wczesnośredniowiecznych autorów zob. M. Hardt, The Nomad's Greed for Gold. From the Fall of the Burgundians to the Avar Treasure, w: The Construction of Communities in the Early Middle Ages. Texts, Resources and Artefacts, red. R. Corradini i in., Leiden-Boston 2003, s. 95-107.

${ }^{23}$ Prokopiusz De Bellis, VI, 14, 36, s. 413.

${ }^{24} \mathrm{H}$. Wolfram łączy tę opowieść z jedną z podstaw ideowych wczesnośredniowiecznej monarchii, a mianowicie posiadaniem przez króla „dziedzicznej charyzmy” (ein Erbcharisma); tenże, Rom und das frühe Königtum nördlich der Alpen, w: tenże, Gotische Studien. Volk und Herrschaft im frühen Mittelalter, München 2005, s. 15-65, zwł. s. 29.

${ }^{25}$ B. Rubin twierdzi, że Prokopiusz z Cezarei nienawidził Herulów, ponieważ wiernie służyli oni Narsesowi, ale nie chcieli walczyć pod Belizariuszem, który był bohaterem Prokopiusza; zob. tenże, Das Zeitalter Iustinians, t. 1, Berlin 1960, s. 437, przyp. 519. Podobne wnioski wysunął W. Goffart, Barbarian Tides, s. 207. 
Rodulf rysuje się w tej opowieści jako postać arcyciekawa. Amerykański badacz Walter Goffart nazywa go „biednym” (,poor Rudolf”26), sugerując, że wina za klęskę spada wyłącznie na oskarżających go o tchórzostwo i zniewieściałość Herulów. Sprawa przedstawia się jednak zgoła inaczej. Przez

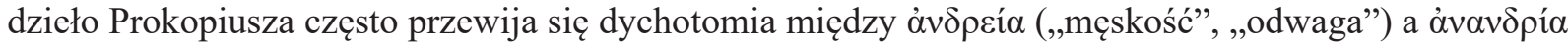
(„niemęskość”, „tchórzostwo”) ${ }^{27}$. Oskarżenia o tchórzostwo i zniewieściałość kierowane przez żołnierzy pod adresem własnego dowódcy stanowią motyw często pojawiający się w jego narracji. Idealny wódz według Prokopiusza powinien pozostać niewzruszony, nawet jeśli jego wojownicy nazywają przyjętą przez niego strategię tchórzliwą lub zniewieściałą ${ }^{28}$. Jeśli odpowiedzią na oskarżenia o brak męstwa jest lekkomyślny pokaz odwagi, to rezultatem jest zwykle sprowadzenie na siebie klęski ${ }^{29}$. Spójrzmy choćby na relację Prokopiusza o wydarzeniach poprzedzających bitwę pod Callinicum ${ }^{30}$ (531). Pierwotnie Belizariusz nie chciał zaatakować Persów, ponieważ uznał, że lepiej będzie, jeśli pozwoli im się odejść bez walki do ich własnego kraju. Sądził on, że wystarczy, iż wróg będzie zmuszony do odwrotu, nic nie zdziaławszy na rzymskim terytorium. Widząc, że Belizariusz chce uniknąć starcia, które w mniemaniu jego żołnierzy niechybnie zakończyłoby się zwycięstwem, zarówno oni, jak ich oficerowie zaczęli z niego skrycie kpić. Spostrzegłszy, że wszyscy żołnierze chcą wyruszyć przeciwko wrogowi, Belizariusz postanowił odwieść ich od tego pomysłu. Przemówił do nich, argumentując m.in., że wprawdzie Bóg wspomaga ludzi w niebezpieczeństwie, ale nie jeśli znajdą się w nim z własnej woli ${ }^{31}$. Żołnierze jednak nie zważali na jego słowa i zaczęli obrażać go, nazywając słabeuszem. Słysząc to, Belizariusz zmienił zdanie i sam zaczął zagrzewać żołnierzy do walki, dając w końcu rozkaz do ataku. Bitwa skończyła się klęską wojsk wschodniorzymskich. Wina za porażkę spadła zarówno na chcących bitwy żołnierzy, jak i na nieumiejącego odwieść ich od tego zamiaru wodza. Idealny przywódca, według Prokopiusza, powinien charakteryzować się odwagą, mądrością i być powściągliwy ${ }^{32}$. Rodulf - wbrew W. Goffartowi - nie był „biedny” i niewinny, lecz wina za klęskę spada również na jego barki, ponieważ nie okazał pożądanych cech, dając się swoim wojownikom sprowokować i nierozważnie wydając rozkaz do wymarszu. To była pierwsza z przyczyn klęski Herulów.

Jakże odmiennie ukazani są w tej opowieści przeciwnicy herulskich „schwarzcharakterów” - Longobardowie. Prokopiusz podkreśla, że Herulowie wymaszerowali przeciw Longobardom, choć ci nie zrobili im nic złego. Lud Rodulfa nie oskarżył ich o żaden występek lub pogwałcenie zawartej umowy - dodam, że chodzi o umowę, na mocy której Longobardowie zobowiązali się płacić trybut Herulom. Wojna rozpoczęła się bez żadnego ważnego powodu. Mało tego, dziejopis relacjonuje, że gdy Longobardowie dowiedzieli się, iż Herulowie ruszyli zbrojnie przeciw nim, natychmiast wysłali poselstwo, które domagało się wyjaśnienia, czemu Rodulf i jego współplemieńcy chwycili za broń. Jeśli przyczyną było to, że Herulowie dotychczas nie otrzymali trybutu, to teraz otrzymają go, i to z nawiązką. Jeśli zaś to, że Herulowie uznali, iż narzucony trybut był za niski, to Longobardowie nie będą mieć oporów, aby płacić wyższy. Rodulf, grożąc emisariuszom, odrzucił wszystkie propozycje, odesłał poselstwo i wznowił marsz. Longobardowie wysłali drugie poselstwo, które przybyło do Herulów z błagalnymi prośbami, ale i ono wróciło z niczym. Wreszcie wysłali trzecie, które zabroniło Herulom podejmowania działań wojennych bez wyraźnego powodu, a jeśli nawet przybyliby zbrojnie - oświadczyli posłowie to Longobardowie staną z bronią $\mathrm{w}$ ręku przeciwko najeźdźcom - nie z własnej woli, lecz powodowani

\footnotetext{
${ }^{26}$ W. Goffart, Barbarian Tides, s. 208.

27 Zob. M.E. Stewart, Contest of Andreia in Procopius' Gothic Wars, „Parekbolia”, 4, 2014, s. 21-54, zwł. s. 22. Na temat $\grave{\alpha} v \delta \rho \varepsilon i ́ \alpha$ zob. K. Bassi, The Semantics of Manliness in Ancient Greece, w: Andreia. Studies in Manliness and Courage in Classical Antiquity, red. R.M. Rosen, I. Sluiter, Leiden-Boston 2003, s. 25-58; M. McDonnell, Roman Manliness. Virtus and the Roman Republic, Cambridge 2006, passim.

28 Jak stwierdza M.E. Stewart, Contest, s. 36.

29 C. Whately, Battles and Generals. Combat, Culture, and Didacticism in Procopius' Wars, Leiden 2016, s. 97.

${ }^{30}$ Prokopiusz De Bellis, I, 18, 13-29, s. 160-169; zob. też C. Whately, Battles, s. 89-90; tenże, Jordanes, the Battle of the Catalaunian Plains, and Constantinople, „Dialogues d'histoire ancienne”, 8, 2013, s. 65-78, zwł. s. 75-76.

${ }^{31}$ Prokopiusz De Bellis, I, 18, 21, s. 106-107.

${ }^{32}$ M.E. Stewart, Contest, 31.
} 
koniecznością ${ }^{33}$. Następnie wezwali oni Boga na swego świadka i ogłosili wrogom, że najdrobniejsze tchnienie Jego przychylności może przeważyć szalę oraz przeciwstawić się całej ludzkiej sile i właśnie On - będąc do głębi poruszony przyczynami wojny - zdecyduje o losach starcia. Longobardowie wygłosili te słowa, chcąc przerazić nieprzyjaciół, ci jednak bez skrupułów zdecydowali się stoczyć bitwę.

Zastanawia mnie jedno. Otóż Longobardowie ogłosili, że w bitwie będą mieć Boga po swej stronie. To On sprawić miał, ich zdaniem, że Herulowie stracą swoje atuty - przewagę liczebną oraz potęgę i - jak pozwalam sobie dodać - większą wprawę w wojennym rzemiośle. Skąd jednak fabularni Longobardowie czerpali przekonanie, że Bóg będzie po ich stronie? Po pierwsze (jak już wspominałem przy okazji przemowy Belizariusza skierowanej do jego żołnierzy), według Prokopiusza Bóg zawsze wspomaga ludzi znajdujących się w niebezpieczeństwie, ale tylko tych, którzy znaleźli się w nim nie z własnej woli. Po drugie, Bóg staje po stronie tych, którzy są pokorni i robią wszystko, aby uniknąć niepotrzebnego rozlewu krwi. Aby zilustrować ten drugi motyw, przytoczmy relacje pochodzące z dzieł dwóch innych dziejopisów.

Grzegorz z Tours relacjonuje w swoich Historiae o wyprawie frankijskiego króla Chlotara I przeciwko Sasom $^{34}$. Gdy objął on po śmierci Teudebalda jego królestwo - rzecz zdumiewająca, Grzegorz nazywa tę część frankijskiej domeny mianem regnum Franciae ${ }^{35}$ - Sasi przestali uiszczać coroczną daninę ${ }^{36}$. Chlotar zareagował natychmiast i na czele swych wojsk wyprawił się przeciwko nim, a gdy był już blisko granicy, Sasi wysłali posłów, którzy oznajmili królowi, że chętnie zapłacą daninę, a nawet więcej, jeśli będzie trzeba, ale proszą, aby armia Chlotara i ich własny lud nie starły się w walce. Chlotar wysłuchał Sasów i rzekł do swoich ludzi: „Dobrze mówią ci ludzie. Nie ruszajmy przeciw nim, z obawy, abyśmy nie zgrzeszyli przeciwko Bogu" ${ }^{37}$. Frankijscy wojownicy nie uznali jednak poważnego argumentu Chlotara i dalej chcieli rozprawić się z Sasami zbrojnie. Sasi złożyli wtedy drugą ofertę oddania połowy swych dóbr, chcąc tylko pokoju. Chlotar wygłosił do swych współplemieńców błagalne słowa: „Odstąpcie, błagam was, od tych ludzi, aby gniew Boży nie powstał przeciw nam”" ${ }^{38}$. Frankowie znów nie przyjęli rady swego monarchy. Sasi zaoferowali swe szaty, bydło oraz wszelkie dobra i zachęcili Franków, aby ci wzięli wszystko wraz z połową ziem. Pragnęli tylko, aby ich żony oraz maleństwa pozostały wolne i aby między nimi a Frankami trwał pokój. Frankowie pozostali głusi na te prośby i po raz kolejny Chlotar zaapelował do ich serc i sumień: „Odstąpcie, błagam was, odstąpcie od tego zamiaru. Słowa (zamiaru) bowiem słusznego nie mamy; nie idźcie na wojnę, w której się wygubicie. Jednak jeśli chcecie iść, ja z własnej woli z wami nie pójdę "39. Frankowie wpadli w szał i chcieli nawet zabić króla,

33 J. Banaszkiewicz twierdzi, że odrzucenie przez Herulów trzech poselstw jest w gruncie rzeczy popełnieniem „trzech przestępstw wobec każdej z trzech dziedzin ludzkiej-wspólnotowej działalności”. Herulowie sami skazali się na klęskę, lekceważąc „świat w jego trójdzielnym i trójfunkcyjnym porządku”; tenże, Rodulf, s. 30. Badacz ten odwołał się do koncepcji „trzech przewin wojownika" G. Dumézila, wskazując przy tym, że odrzucając trzy poselstwa, Herulowie nie mieli powodu do rozpoczęcia wojny, nie mieli litości i nie chcieli zdobyczy. Na temat „trzech przewin wojownika” zob. G. Dumézil, The Destiny of the Warrior, tłum. A. Hiltebeitel, Chicago-London 1970; tenże, The Stakes of the Warrior, thum. D. Weeks, Berkeley-Los Angeles-London 1983. Każda z trzech przewin wojownika z związana jest z jedną z trzech funkcji w Dumézilowskim trójdzielnym modelu - są nimi odpowiednio władza zwierzchnia, wojowniczość oraz płodność wraz z obfitością.

${ }^{34}$ Gregorii episcopi Turonensis libri historiarum, wyd. B. Krusch, W. Levison, w: MGH, Scriptores rerum Merovingicarum, t. 1, cz. 1, Hannoverae 1951 [dalej: Grzegorz z Tours, Historiae].

${ }^{35} \mathrm{Na}$ temat tej nazwy zob. H. Reimitz, History, Frankish Identity and the Framing of Western Ethnicity, 550-850, Cambridge 2015, s. $62-65$.

${ }^{36}$ Grzegorz z Tours, Historiae, IV, cap. 14, s. 145-147. Na temat tych wydarzeń zob. E. Zöllner, Geschichte der Franken bis zur Mitte des sechsten Jahrhunderts, München 1970, s. 102; F. Lot, Naissance de la France, Paris 1948, s. 59-61; E. Ewig, Die Merowinger und das Frankenreich, Stuttgart 1988, s. 84; I. Wood, The Merovingian Kingdoms, 450-751, London-New York 1994, 163; B.S. Bachrach, Merovingian Military Organization, 481-751, Minneapolis 1972, s. 28. Bachrach - jak na klasycznego historyka wojskowości przystało - nie zadaje sobie trudu, aby dokonać choćby pobieżnej analizy rozwiązań fabularnych zastosowanych przez Grzegorza z Tours.

${ }^{37}$ Grzegorz z Tours, Historiae, IV, cap. 14, s. 146: „Bene locuntur hii homines. Non incedamus super eos, ne forte peccemus in Deum".

38 Tamże: „Dissistete, quaeso, ab his hominibus, ne super nos Dei ira concitetur”.

39 Tamże: „Desistite, quaeso, desistite ab hoc intentione. Verbum enim derictum non habemus; nolite ad bellum ire, in quo disperdamini. Tamen si abire volueritis, spontatia voluntate ego non sequar". 
Chlotar ze strachu zdecydował się więc ruszyć z nimi przeciw Sasom. Obawy władcy spełniły się co do joty. W bitwie Frankowie ponieśli wielką klęskę i zapłacili za swą arogancję ogromnymi stratami.

Trzy przemowy Chlotara pozwalają zrozumieć, czemu Longobardowie uważali, że będą mieć Boga po swej stronie. Herulowie nie mieli żadnego słusznego i sprawiedliwego powodu, by rozpocząć działania wojenne, a bez niego narażali się na gniew Najwyższego. Longobardowie i Sasi pełni pokory zdecydowani byli oddać wrogom część swoich dóbr, tylko po to, aby zachować pokój. Pokora Sasów sprawiła, że Bóg stanął po ich stronie i właśnie On, nagradzając ich zachowanie, dał im zwycięstwo ${ }^{40}$. Jak zobaczymy dalej, również pokora Longobardów sprawiła, że Pan w Niebiosach obdarzył ich wspaniałą wiktorią.

Podobny wątek fabularny znajdujemy jeszcze u Pawła Diakona ${ }^{41}$. Powiada on, że Sasi, którzy ongiś opuścili swe rodzime pielesze, po wielu wyprawach powrócili do ojczystych ziem. Nie zastali ich pustymi - saską ojczyznę zamieszkiwali teraz Swebowie i jakieś jeszcze inne - niewymienione z nazwy - ludy. Sasi, chcąc odzyskać swe dawne włości, postanowili ich wypędzić i zniszczyć. Pełni pokory Swebowie ofiarowali Sasom trzecią część swej ziemi, przecież - tak argumentowali - wszyscy mogli razem żyć w pokoju na tym samym terytorium. Sasi nie chcieli przystać na tę propozycję. Swebowie zaoferowali połowę swych ziem, wreszcie dwie trzecie, sobie zostawiając ledwie jedną trzecią całego terytorium. Sasi jednak nie zgodzili się na to. Ostatnia oferta była wyjątkowo hojna - Sasom zaoferowano całe bydło, byleby tylko powstrzymali się od rozpoczęcia wojny. Sasi żądni byli walki i jeszcze przed bitwą umówili się, w jaki sposób podzielą między siebie żony Swebów. Bitwę jednak sromotnie przegrali - na polu walki legło 20 tys. Sasów, podczas gdy Swebowie stracili ledwie 480 ludzi. Paweł Diakon oczywiście zaczerpnął tę relację od Grzegorza z Tours ${ }^{42}$, który zaraz po przytoczeniu wzmianki o podziale swebskich żon wprost wyjaśnia, czemu Sasi skazani byli na klęskę: „Lecz współczucie Pańskie, które czyni sprawiedliwość, obróciło ich zamiar w przeciwną stronę"43. Bóg - jak wynika i z tej wersji - stanął po stronie pokornych i sprawiedliwych Swebów, a na pełnych buty i niesprawiedliwych Sasów spadła klęska. Powróćmy teraz do Prokopiuszowej opowieści o bitwie.

Gdy wszelkie negocjacje spaliły na panewce, obie armie stanęły naprzeciw siebie. Wtem nad Longobardami zawisła gęsta i czarna chmura, nad herulską armią zaś niebo było przejrzyste. Prokopiusz komentuje, że wnosząc po tym niezwykłym zjawisku, ktoś mógłby przypuszczać, iż Herulowie idą do boju na własną zgubę, ponieważ nie istnieje dla barbarzyńców bardziej złowieszczy omen, gdy ruszają do bitwy. Herulowie jednak całkowicie lekceważąc ten znak, ruszyli w bój z całkowitą pogardą dla wrogów, zakładając pomyślne dla nich rozstrzygnięcie starcia na podstawie swej przewagi liczebnej. Bitwę oczywiście przegrali, w walce poległ Rodulf z dużą częścią wojowników, wielu Herulów zginęło podczas ucieczki i tylko nieliczni zdołali ujść z życiem.

Logika fabuły wskazuje oczywiście na związek przyczynowo-skutkowy między butą Herulów, brakiem słusznego i sprawiedliwego powodu rozpoczęcia działań wojennych a ich miażdżącą klęską. Ta sama logika każe sądzić, że Longobardowie - mimo że walczyli z wrogiem liczebniejszym i bardziej zaawansowanym w wojennym rzemiośle - swoją pokorą pozyskali przychylność Najwyższego. To on dał im zwycięstwo w bitwie z Herulami, którzy butnie zaatakowali niewinnych i pełnych pokory ludzi. Po prostu wojna, którą rozpoczęli Herulowie, była wojną niesprawiedliwą ${ }^{44}$.

Jest jeszcze jeden motyw w opowieści Prokopiusza, który wymaga omówienia. Co zrobić z ową czarną i gęstą chmurą, która unosiła się nad longobardzkim hufcem? Jak zinterpretować to niezwykłe

40 P. Żmudzki mówi o „wynagrodzonej pokorze”; tenże, Władca $i$ wojownicy, s. 116.

${ }^{41}$ Paweł Diakon, Historia Langobardorum, III, cap. 7, s. 95.

${ }^{42}$ Grzegorz z Tours, Historiae, V, cap. 15, s. 213-214. O źródłach wykorzystanych przez Pawła zob. Th. Mommsen, Die Quellen der Langobardengeschichte des Paulus Diaconus, w: tenże, Gesammelte Schriften, t. 6: Historische Schriften, t. 3, Berlin 1910, s. 485-539.

${ }^{43}$ Grzegorz z Tours, Historiae, V, cap. 15, s. 214: „Sed Domini miseratio, quae iustitiam facit, in aliam partem voluntatem eorum retorsit".

44 Jak przypomina F.H. Russell (The Just War in the Middle Ages, Cambridge 1975, s. 3), to Arystoteles ukuł termin „,wojna sprawiedliwa". 
zjawisko? Było ono - jak wiemy od samego Prokopiusza - znakiem, który wieszczył klęskę Herulów, ale czy tylko tym? Dla wyjaśnienia znaczenia tego motywu sięgnijmy znów do materiału porównawczego. Zacznijmy od Pisma Świętego ${ }^{45}$. Ciemna chmura jest w Świętej Księdze znakiem Bożego gniewu. W Lamentacjach czytamy, że Pan w gniewie okrył córkę Syjonu ciemną chmurą ${ }^{46}$. Czy zatem ciemna chmura $\mathrm{w}$ analizowanej tu opowieści była znakiem gniewu Bożego i obecności Najwyższego na polu bitwy? Przytoczmy jeszcze relację historiograficzną. Pogański historyk Eunapios z Sardes (IV-V w.) ostro krytykował przekonanie chrześcijan, że to nie dzielność żołnierzy i osobista odwaga cesarzy pozwoliła im zwyciężać w bitwach, lecz wynik boju zależny był od woli Boga ${ }^{47}$. Około $400 \mathrm{r}$. Eunapios pomstował, że pewien prefekt Rzymu wystawił malowidła, które według historyka wyśmiewały i wyszydzały zwycięstwa odniesione przez Rzymian. Szczególnie jeden motyw widniejący według Eunapiosa na owych malowidłach wart jest naszej uwagi - ręka wychodząca z chmury. Cóż miała ona symbolizować? Odpowiedzi udziela relacja samego Eunapiosa - na legendzie malowidła widniały dwa napisy: ten, który zawarty został na jednej stronie, głosił: „ręka Boga przepędza barbarzyńców”, ten na drugiej - „barbarzyńcy uciekają przed Bogiem”48. Wyjątkowo negatywna reakcja Eunapiosa jest dla nas zrozumiała. Co dla poganina było nie do pomyślenia, warte śmiechu lub wręcz żałosne, dla chrześcijanina było prawdą, którą objawił sam Bóg i o której nauczała Święta Księga. Bóg był - według chrześcijańskich przekonań - obecny na polu bitwy i aktywnie uczestniczył w walce ${ }^{49}$. Wiara w to była starsza niż samo chrześcijaństwo. W Piśmie Świętym chmura unosząca się nad Ludem Wybranym jest znakiem Boskiej protekcji ${ }^{50}$. „Nie bójcie się, nie lękajcie się! Gdyż z wami wyrusza Pan, Bóg wasz, by walczyć przeciw wrogom waszym i dać wam zwycięstwo" - głosi Księga Powtórzonego Prawa ${ }^{51}$. I w to wierzono oczywiście we wczesnym średniowieczu - „Bóg stoi po stronie tego, który walczy w słusznej sprawie", jak skomentował rzecz John Michael Wallace-Hadrill ${ }^{52}$. Bóg w relacji Eunapiosa wyciągał swą rękę zza obłoku i przepędzał barbarzyńskie watahy, co pozwala sądzić, że chmura, która według relacji Prokopiusza pojawiła się nad longobardzkim hufcem, świadczyć miała, iż to sam Bóg stanął przeciwko Herulom i zadał im klęskę.

Motyw udziału Boga w bitwie po stronie sprawiedliwych wojowników pojawia się oczywiście u Prokopiusza jeszcze w innym miejscu ${ }^{53}$. Przytacza on mowę gockiego króla Totili wygłoszoną do jego wojsk. Władca wyjaśnił swoim żołnierzom rzecz niezwykłą, otóż wytłumaczył im szczegółowo, dlaczego kiedyś licząca 200 tys. najwaleczniejszych wojowników armia w sprzyjających dla niej okolicznościach została pobita przez ledwie 7 tys. Greków. Przyczyną takiego rozstrzygnięcia bitwy było to, że Goci zachowywali się źle względem siebie i swoich rzymskich poddanych. $Z$ tego właśnie powodu Bóg stanął po stronie ich nieprzyjaciół. Mimo że Goci byli liczniejsi, dzielniejsi, lepiej uzbrojeni i do dyspozycji mieli najroztropniejszych starców, którzy służyli wojsku mądrymi radami, to zostali pobici przez niewidzialną i niezrozumiałą siłę. Totila zaapelował do swoich wojowników, aby zawsze byli sprawiedliwi i postępowali właściwie, bo jeśli zmienią swe nastawienie, to Bóg również zmieni swój stosunek do

${ }^{45}$ Czarna, złowróżbna chmura w tradycji żydowskiej pojawia się zwykle w związku z teofaniami; zob. K.C. Bautch, $A$ Study of the Geography of 1 Enoch 17-19 „,No One Has Seen What I Have Seen”, Leiden-Boston 2003, s. 57-59.

${ }^{46} \operatorname{Lm~} 2,1$.

47 Zob. R.C. Blockley, The Fragmentary Classicizing Historian of the Later Roman Empire, t. 1-2, Liverpool 1983, tu t. 2, s. 109.

${ }^{48} \mathrm{Na}$ temat relacji Eunapiosa zob. D. Woods, A Persian at Rome. Ammianus and Eunapius, Frg. 68, w: The Late Roman World and Its Historian. Interpreting Ammianus Marcellinus, red. J.W. Drijvers, D. Hunt, London-New York 2002, s. 138-146; M.W. Graham, News and Frontier Consciousness in the Late Roman Empire, Ann Arbor 2006, s. 94; M. McCormick, Eternal Victory. Triumphal Rulership in Late Antiquity, Byzantium and the Early Medieval West, Cambridge 1987, s. 96; C. Ando, Imperial Ideology and Provincial Loyalty in the Roman Empire, Berkeley-Los Angeles-London 2000, s. 255.

49 J.M. Wallace-Hadrill, War and Peace in the Earlier Middle Ages, „Transactions of the Royal Historical Society”, 25, 1975, S. 158.

${ }^{50}$ Zob. 1 Kor 10,1-2. Na temat symbolu obłoku w Biblii zob. P.D. Gardner, The Gifts of God and the Authentication of a Christian. An Exegetical Study of 1 Corinthians 8-11:1, Lanham-New York-London 1994, s. 116, 119; B.J. Oropeza, Paul and Apostasy. Eschatology, Perseverance, and Falling Away in the Corinthian congregation, Tübingen 2000, s. 92-99.

51 Pwt 20,4; por. J.M. Wallace-Hadrill, War and Peace, s. 158.

52 J.M. Wallace-Hadrill, War and Peace, s. 168.

${ }^{53}$ Prokopiusz De Bellis, VII, 21, 4-11, s. 334-337. 
nich. Jego łaska przestanie ich wspierać i obróci się przeciw nim. Jeśli zaś będą dobrze traktować siebie nawzajem i swoich poddanych, to ich powodzenie w toczącej się wojnie będzie zagwarantowane.

Zwróćmy uwagę na jeszcze jedną kwestię, mianowicie kolejną możliwą przyczynę walki Boga po stronie Longobardów. Byli oni, oczywiście według Prokopiusza, chrześcijanami, ale mało tego, ustępowali Herulom liczebnością, a przecież Ojciec Niebieski - jak wierzono - zawsze walczy przeciw poganom po stronie swych wyznawców, szczególnie jeśli ci są nieliczni. Przytoczmy choćby klasyczny już fragment Vita Wilfridi, której autor relacjonował bitwę stoczoną przez biskupa Yorku przeciw pogańskim południowym Sasom. Wilfryd, stojąc na czele ledwie 120 ludzi, zmuszony był zmierzyć się z ogromną armią pogan. Trzy razy zwyciężył przeważających liczebnie wrogów, bo „Pan mianowicie walczył za nielicznych" ${ }^{54}$.

Zakończmy w tym miejscu rozważania nad relacją Prokopiusza o wojnie longobardzko-herulskiej krótkim komentarzem. Fabuła przytoczonej przez tego wschodniorzymskiego dziejopisa opowieści zasadza się na związku przyczynowo-skutkowym między niesprawiedliwym postępowaniem Herulów a karą, którą niebiosa wyznaczyły im za ich przewiny. Wnosząc po opisie bitwy zawartym przez Prokopiusza w De Bellis, tego pamiętnego dla Longobardów dnia Bóg - pod postacią czarnej i gęstej chmury - chronił ten pokorny oraz sprawiedliwy lud i walczył po jego stronie przeciwko dzikim, aroganckim i niesprawiedliwym Herulom ${ }^{55}$.

\section{Wojna Herulów z Longobardami - wersja Pawła Diakona}

Wersja zaprezentowana przez Pawła Diakona jest równie bogata w wątki fabularne. Konflikt wojenny według tego dziejopisa wybucha z winy Longobardów. Otóż - w wielkim skrócie - pewna longobardzka niewiasta o imieniu Rumetruda rozkazała zamordować nieznanego nam z imienia brata króla Rodulfa. Władca Herulów nie miał wyboru. Chcąc pomścić śmierć brata, musiał rozpocząć działania wojenne. Gdy przybył ze swą armią na pole bitwy, wysłał swoich wojowników do boju, a sam pozostał w obozie wojskowym. Dlaczego herulski król osobiście nie wziął udziału w bitwie i nie stanął na czele swych wojowników? Paweł Diakon relacjonuje, że Rodulf „w nadzieję na zwycięstwo żadną miarą nie wątpiąc" ${ }^{56}$, pozostał w obozie. Powiedzielibyśmy, że zwycięstwo było dla herulskiego władcy rzeczą tak pewną, iż nie widział on potrzeby, aby osobiście wziąć udział w boju. Przekonanie to wynikało z tego, że Herulowie - jak pisze Paweł Diakon - „,byli zaprawieni w prowadzeniu wojen i znani z bardzo wielu zwycięstw" 57 . Rodulf nie brał bezpośredniego udziału w walce, lecz zabawiał się - jakąś bliżej nieokreśloną - grą ${ }^{58}$. Jego niezwykłe w naszych oczach zachowanie Paweł Diakon znów wyjaśnił wiarą króla w niezwyciężoność swych wojowników: „W ich męstwie król pokładał tak niezachwianą wiarę, że sam pewny (lub: »bez obawy«) zabawiał się grą przy stole" ${ }^{59}$. Widzimy w zachowaniu monarchy butę, niezachwianą pewność, że jego wojownicy odniosą zwycięstwo, stąd też bierze się oddanie całkowicie niewojowniczemu zajęciu ${ }^{60}$. Sama gra obrazuje czytelnikom stopień zrelaksowania króla, który jest

54 „Dominus enim pro paucis pugnavit”; Vita Sancti Wilfridi episcopi eboracensis auctore Eddio, cap. 13, w: Vita Quorundam Anglo-Saxonum. Original Lives of Anglo-Saxons and Others, who lived before the Conquest, wyd. J.-A. Giles, London 1854, s. 212; The Life of Bishop Wilfrid by Eddius Stephanus, cap. 13, wyd., thum. i kom. B. Colgrave, Cambridge 1927, s. 28.

55 W. Goffart uważa, że wojenny heroizm jest nieobecny we wczesnośredniowiecznych źródłach narracyjnych; zob. tenże, Conspicuously Absent, s. 95-120. Przedstawione przez niego argumenty należy skonfrontować z tezą wysuniętą przez: P. Wormald, Bede, Beowulf and the Conversion of the Anglo-Saxon Aristocracy, w: tenże, The Times of Bede. Studies in the Early English Christian Society and Its Historian, red. S. Baxter, Oxford-Malden (Mass.) 2006, s. 30-105.

${ }^{56}$ Paweł Diakon, Historia Langobardorum, I, cap. 20, s. 58: „de spe victoriae nihil ambigens”.

57 Tamże: „bellorum usibus exerciti multorumque iam strage notissimi”.

${ }^{58}$ Rozważania o tym, jaka to była gra, zob. J. Banaszkiewicz, Rodulf, s. 27.

${ }^{59}$ Paweł Diakon, Historia Langobardorum, I, cap. 20, s. 58: „Horum itaque viribus rex indubitanter fidens, dum ipse securus ad tabulam luderet".

${ }^{60}$ O. Gschwantler twierdzi, że Rodulf prezentuje w narracji Pawła Diakona „lekkomyślne przekonanie o zwycięstwie” (die leichtsinnige Siegesgewißheit), stąd też badacz ten kieruje się ku spekulacjom na temat treści i wymowy ideowej pierwotnej 
tak pewny swego, że w gruncie rzeczy nie bardzo interesuje się przebiegiem bitwy - z relacji Pawła dowiadujemy się, iż zwycięski wynik starcia ma mu oznajmić pewien umyślny, który wspina się na okoliczne drzewo, aby stamtąd obserwować bój i szybciej ogłosić królowi zwycięstwo Herulów, w które Rodulf wierzy niezachwianie. Paweł Diakon powiada, że władca był securus. To ważne spostrzeżenie. Poczucie pewności jest przecież według tego dziejopisa ogólnie jedną z przyczyn klęsk militarnych; „pewność, która zawsze jest matką (= przyczyną) klęsk"61 - komentował Paweł Diakon przy okazji opisania nocnego ataku Bułgarów na obóz Longobardów, podczas którego zginął legendarny król tego ludu, Agelmund. Zachowanie Rodulfa jest więc pierwszą z przyczyn nadchodzącej klęski. Mało tego, motyw kary za zbytnią pewność siebie i przesadną wiarę w zdolności bojowe własnych żołnierzy przywodzi na myśl Biblię. Święta Księga bowiem nie raz relacjonuje, jak zbytnia pewność siebie i zbyt mocne pokładanie wiary w zdolności bojowe żołnierzy Ludu Wybranego rozgniewały Najwyższego, który karał ich klęską w walkach z pogańskimi sąsiadami ${ }^{62}$.

Ze swej strony herulscy wojowie przystępują do bitwy nago, zasłaniając tylko części wstydliwe. Po co to czynią? Zostawmy poza nawiasem rozważań skomplikowane w swej naturze dociekania nad problemem „nagich wojowników” i szukanie odpowiedzi na pytanie, czemu niektóre grupy antycznych oraz średniowiecznych wojów przystępowały do walki bez uzbrojenia, a skoncentrujmy się w tym miejscu tylko na wyjaśnieniu, jakie daje autor naszego źródła ${ }^{63}$. Paweł Diakon komentuje, że uczynili to „albo, żeby łatwiej walczyć, albo, żeby okazać pogardę dla ciosów zadanych przez wroga" ${ }^{64}$. Interesuje mnie tylko druga z podanych przyczyn. Jak sądzę, mamy tu kolejny przykład buty Herulów, bo ich niezwykłe zachowanie demonstrować ma, że gardzili oni wrogiem, zdjęli nawet - jak trafnie odczytują uczeni to, co chciał przekazać swoim czytelnikom Paweł Diakon ${ }^{65}$ - uzbrojenie ochronne, bo w sumie było niepotrzebne, skoro wróg, zapewne prezentujący w mniemaniu herulskich wojów lichą wartość bojową, i tak nie był w stanie nic im zrobićc ${ }^{66}$. Autor uświadamia czytelnikom, że Herulowie tym zachowaniem demonstrują Longobardom, iż są oni w gruncie rzeczy przeciwnikiem niegodnym dla osławionych w bojach, zwycięskich wojów Rodulfa. Okazanie wrogowi jego niewielkiej wartości bojowej jest przecież tradycyjnym rytuałem otwierającym bitwę ${ }^{67}$. Zilustruję teraz ten ryt trzema przykładami. Dean A. Miller uważa, że skandynawscy berserkir są najskrajniejszym przykładem „czempionów” walczących

„pieśni”, która była według niego źródłem tego fragmentu Historia Langobardorum; tenże, Formen, s. 62. Rozwiązanie fabularne, które użyte zostało przez Diakona, nie ma jednak na celu przedstawienia zachowania Rodulfa jako objawu lekkomyślności, lecz buty, wynikającej z całkowitego przekonania o niezwyciężoności jego Herulów.

${ }^{61}$ Paweł Diakon, Historia Langobardorum, I, cap. 16, s. 55: „securitas, quae semper detrimentorum mater est”.

${ }^{62}$ Sh.J.D. Cohen twierdzi, że kara Boska za arogancję i przesadną pewność siebie jest paradygmatem żydowskiej historii; zob. tenże, The Significance of Yavneh and Other Essays in Jewish Hellenism, Tübingen 2010, s. 523.

${ }^{63}$ Problem tzw. nagich wojowników ma długą tradycję badawczą; zob. np.: E.A. Thompson, Early Germanic Warfare, „Past \& Present”, 14, 1958, s. 2-29, zwł. s. 4 i 23, przyp. 17; J. Banaszkiewicz, „, Nadzy wojownicy” - o średniowiecznych pogłosach dawnego rytu wojskowego (Prokopiusz z Cezarei, Pawet Diakon, Girald z Walii, Sakso Gramatyk i Gall Anonim), w: tenże, Takie sobie średniowieczne bajeczki, wprow. M. Tomaszek, Kraków 2012, s. 361-389; P. Vidal-Naquet, Les Jeunes. Le cru, l'enfant grec, et le cuit, w: Faire de l'histoire, t. 3: Nouveaux objects, red. J. Le Goff, P. Nora, Paris 1974, s. 137-168; tenże, Le chasseur noir et l'origine de l'éphébie athénienne, „Annales. Économies, Sociétés, Civilisations”, 23, 1968, nr 2, s. 947-964; B. Sergent, Les troupes de jeunes hommes et l'expansion indo-européenne, „Dialogues d'histoire ancienne”, 29, 2003, nr 2, s. 9-27; M.P. Speidel, Berserks. A History of Indo-European „Mad Warriors”, „Journal of World History”, 13, 2002, nr 2, s. 253-290; tenże, Ancient Germanic Warriors. Warrior Styles from Trajan's Column to Icelandic Sagas, London-New York 2004.

${ }^{64}$ Paweł Diakon, Historia Langobardorum, I, cap. 20, s. 58: „sive ut expeditius bella gererent, sive ut inlatum ab hoste vulnus contemnerent".

${ }^{65}$ D. Bianchi, L'elemento epico nella „Historia Langobardorum”, „Memorie Storiche Forogivliesi”, 30, 1934, nr 1, s. 133-134; J. Banaszkiewicz, Rodulf, s. 25.

${ }^{66}$ H.M. Chadwick łączył „nagość” Herulów z „konserwatywnymi instynktami” tego ludu, które związane były według niego z kultem Odyna; zob. tenże, The Cult of Othin. An Essay in the Ancient Religion of the North, Cambridge 1899, s. 40 .

${ }^{67}$ Jak pisał D.A. Miller, wróg/przeciwnik musi być uważany za godnego walki. Musi zostać uznany za równego bohaterowi, z którym ma skrzyżować miecze. Jeśli nie jest, próbuje się mu okazać rytualną wzgardę; tenże, The Epic Hero, Baltimore-London 2000, s. 217. 
bez uzbrojenia ochronnego w celu okazania wrogowi pogardy ${ }^{68}$. Nawet więcej, berserkowie nie tylko walczą bez zbroi, ale odrzucają również tarcze, aby „siec wrogów obiema rękami”. Przykładów wartych przytoczenia jest więcej. Plutarch w Żywocie Mariusza powiada, że barbarzyńscy Cymbrowie przed bitwą z Rzymianami z pogardy dla swoich nieprzyjaciół nago stawiali czoło szalejącym śnieżycom $^{69}$, aby okazać wrogom swą siłę i odwagę ${ }^{70}$. Ryt zdejmowania przed walką uzbrojenia ochronnego w celu okazania wrogowi pogardy, który być może jest w swej naturze niezwykle archaiczny, znany był również w czasach nowożytnych ${ }^{71}$.

Okazanie Longobardom pogardy przez Herulów jest czytelną w relacji Pawła Diakona przyczyną przystąpienia do walki nago. $Z$ drugiej strony, ich zachowanie można przyrównać do działań podjętych przez Sasów ze wspomnianej już relacji Grzegorza z Tours o ich wojnie ze Swebami. Po klęsce w pierwszej bitwie złożyli oni uroczystą przysięgę, że nie będą obcinać włosów na głowie i golić bród, dopóki nie pomszczą się na wrogach ${ }^{72}$. Zabieg ten na niewiele się jednak zdał, bo Swebowie, mający po swej stronie Boga, zadali Sasom jeszcze większą klęskę. Co miało dać Sasom złożenie owej przysięgi, polegającej na nieścinaniu włosów i niegoleniu bród? Tego Grzegorz nie objaśnia - prawdopodobnie było to dla jego czytelników rzeczą tak oczywistą, że żadne wyjaśnienie nie było potrzebne. Ogólnie, nieścinanie włosów do pewnego wieku, które przerywano rytualnymi postrzyżynami, stanowiło zabieg magiczny, swoiste ślubowanie bóstwu, mające zapewnić w zamian jego protekcję ${ }^{73}$. Być może przysięga złożona przez Sasów miała zapewnić im wsparcie bóstw i pomoc w zwyciężeniu Swebów, a Grzegorzowi pozwoliła wzmocnić przesłanie, że żadne pogańskie, magiczne zabiegi na niewiele się zdadzą, gdy chrześcijański Bóg wspiera drugą stronę konfliktu. Zdjęcie uzbrojenia ochronnego miało uczynić wojownika odpornym na wszelakie pociski i broń sieczną ${ }^{74}$. Przytoczmy choćby znaną z dzieła Saksona Gramatyka opowieść o duńskim królu o imieniu Haraldr hilditönn ${ }^{75}$. Do boju przystąpił on bez zbroi, miał na sobie tylko koszulę. Rzucone w jego stronę oszczepy - tak stawia sprawę Sakso - pozbawione zostały swej niszczącej mocy, tak jakby miały stępione groty ${ }^{76}$. Być może również wzmianka

68 Tamże, s. 214; podobnie zob. M.P. Speidel, Berserks, s. 261 n.; H. Kuhn, Kämpen und Berserker, „Frühmittelalterliche Studien", 2, 1968, s. 218-227; H. Hiltmann, Von nackten Brüsten und blanken Schwertern. Offensive Formen der weiblichen Brustentblößung am Beispiel der ,Eiriks daga rauða”, K. 11, w: Und sie erkannten, dass sie nackt waren, red. S. Bießenecker, Bamberg 2008, s. 413-436, zwł. s. 419, przyp. 24.

${ }^{69}$ Warto jednak w tym miejscu zwrócić uwagę, że w starożytnych Indiach istniał ryt mający na celu uspokojenie burzy, który wymagał stawienia czoła zawierusze nago z mieczem, żagwią lub maczugą w ręku (Kauśika Sütra, 38, 4); zob. R.D. Woodward, Myth, Ritual, and the Warrior in Roman and Indo-European Antiquity, Cambridge 2013, s. 248. Istnieje zatem niebezpieczeństwo, że rzymscy obserwatorzy nie zrozumieli sensu rytualnego zachowania Cymbrów.

${ }^{70}$ C. Marius, w: Plutarchii Vitae, cap. 23, 3, t. 1, wyd. T. Doehner, Parisiis 1857, s. 499.

71 Zob. D.A. Miller, The Epic Hero, s. 214; R. Chambers, History of the Rebellions in Scotland under the Marquis of Montrose, and others. From 1638 till 1660, t. 2, Edinburgh 1828, s. 95 n.

${ }^{72}$ Grzegorz z Tours, Historiae, V, cap. 15, s. 214. Norweski władca Harald Pięknowłosy złożył przysięgę, że nie będzie czesał i ścinał swych włosów, dopóki nie zdobędzie całej Norwegii. Jak tłumaczyć to niezwykłe zachowanie? B. Lincoln wyjaśnia rzecz następująco: „Further, he could have constituted the campaign of military violence through which Harald raised himself to the throne as a sacred mission like that undertaken by Váli: righteous vengeance, the restoration of proper order, and/or a salvific action that averted cosmic disaster"; tenże, Intertextual Silence and Veiled Critique. Snorri on Harald Fairhair and Váli Hözr's-slayer, w: Kontinuität und Brüche in der Religionsgeschichte. Festschrift für Anders Hultgård zu seinem 65. Geburtstag am 23.12.2001, red. M. Strausberg, Berlin-New York 200, s. 485-491, cyt. ze s. 489; tenże, Between History and Myth. Stories of Harald Fairhair and the Founding of the State, Chicago-London 2014, s. 80-94. Dodam, że według Swetoniusza Gajusz Juliusz Cezar na wieść o klęsce jednego ze swoich dowódców, Tyturiusza, w bitwie, w której zginęło wielu jego ukochanych żołnierzy, zapuścił brodę oraz włosy i nie ściął ich zanim ich nie pomścił; zob. De Vita Caesarum, ks. 1, cap. 67, w: Suetonius, t. 1, wyd. M. Ihm, thum. J.C. Rolfe, London-New York 1913, s. 88.

${ }^{73}$ Na temat znaczenia rytuału postrzyżyn i rytualnego noszenia długich włosów zob. szerzej D.L. Leitao, Adolescent Hair-Growing and Hair-Cutting Rituals in Ancient Greece. A Sociological Approach, w: Initiation in Ancient Greek Rituals and Narratives. New Critical Perspectives, red. D.B. Dodd, Ch.A. Faraone, London-New York 2003, s. 109-129, zwł. s. 113.

${ }^{74}$ M. Todd uważa pozyskanie Boskiej protekcji za główny powód walki nago; tenże, The Early Germans, Oxford-Malden 1992, s. 38

75 Saxo Grammaticus, Gesta Danorum, 7, 10, 8, wyd. K. Friis-Jensen, Oxford 2015, s. 496; H. Hiltmann, Von nackten, s. 420.

${ }^{76}$ Największy z mitycznych bohaterów Irlandii, Cú Chulainn, miał w czasie bitwy osiągać stan ríastrad (termin ten oznacza „szał bitewny”), który co prawda nie czynił go odpornym na ciosy i rany, ale żadne uszkodzenie ciała nie osłabiało jego 
o przystąpieniu Herulów do walki nago miała w intencji Pawła Diakona wzmacniać przesłanie, że na nic zdadzą się specjalne zabiegi pogańskich wojowników - jeśli Bóg Jedyny jest przeciw nim.

Wracając do opowieści Pawła Diakona, umyślny, który z wysokości drzewa obserwował przebieg starcia, dostał przykaz, że zapłaci głową, jeśli ogłosi, że wojsko herulskie ucieka. Bitwa toczyła się nie po myśli Herulów i ich szyk załamał się pod siłą longobardzkiego ataku. Jednak na pytanie króla, jak radzą sobie herulskie oddziały, obserwator - bojąc się o własne życie - odpowiedział, że walczą dzielnie. Odważył się stwierdzić coś bliższego prawdzie dopiero gdy Herulowie znajdowali się już w pełnym odwrocie. Krzyknął wówczas: „Biada ci [...] nieszczęsna Herulio, którą karze gniew Pana Niebiańskiego"77. I właśnie w tym miejscu doszukać się można podobieństwa między zachowaniem Sasów z opowieści Grzegorza z Tours a Herulami. Podjęte przez nich specjalne zabiegi, które w pierwszym przypadku polegały na nieścinaniu włosów i bród, a w drugim na walce „nago”, na niewiele się zdały, a skutek tych działań był zgoła odwrotny od zamierzonego - przyczyniły się do jeszcze większej klęski Sasów, a zastosowane w bitwie przeciw Longobardom wzbudziły gniew Pana.

Klęska Herulów była całkowita, ponieważ zawisł nad nimi gniew Niebios, który doprowadził nawet do tego, że zielone łany lnu wzięli za wodę, którą można przepłynąć wpław ${ }^{78}$. Kiedy wojowie herulscy złożyli ramiona jak do pływania, spadły na nich ciosy longobardzkich mieczów.

Gra Rodulfa w czasie bitwy jest nie tylko motywem, który ma demonstrować całkowite lekceważenie przeciwnika i pewność, że Herulowie zwyciężą. Otwiera on Pawłowi Diakonowi pole do wprowadzenia ulubionej przez wczesnośredniowiecznych dziejopisów postaci trickstera - szachraja-przechery, który nie jest $\mathrm{w}$ gruncie rzeczy postacią negatywną ${ }^{79}$. Gdy ów siedzący na drzewie Herul wykrzyczał cytowane powyżej słowa, Rodulf zapytał: „Czy może uciekają moi Herulowie?”80. Odpowiedź umyślnego brzmiała: „Nie ja, lecz ty królu sam to powiedziałeś” ${ }^{1}$. Wywołało to przerażenie króla, który nie wiedząc, co robić, został zaatakowany przez nacierających Longobardów i po dzielnej walce zginął z ich ręki. Gra tocząca się w obozie wojskowym w czasie działań wojennych pojawia się - jak zwrócił uwagę sławny holenderski historyk Johan Huizinga ${ }^{82}$ - również u Pseudo-Fredegara ${ }^{83}$. Dziejopis ten opisuje żałosny koniec „czarnego charakteru” swej narracji, którym był maiordomus Burgundii Protadius, główny zausznik królowej Brunhildy i - jak podejrzewał Pseudo-Fredegar - jej kochanek. Wnuk Brunhildy, król Burgundii Teuderyk II, z jej poduszczenia ruszył na wojnę przeciwko swemu starszemu

waleczności. Na temat ríastrad zob. T. Kinsella, The Táin. From the Irish epic Táin Bó Cuailnge, Oxford 1969, s. 150-153; R. O'Connor, The Destruction of Da Derga's Hostel. Kingship and Narrative Artistry in a Medieval Irish Saga, Oxford 2013, s. 215.

77 Paweł Diakon, Historia Langobardorum, I, cap. 20, s. 59: „Ve tibi [...] misera Herolia, quae caelestis Domini plecteris ira”.

78 Tamże.

79 W historiografii barbarzyńskiego Zachodu motywy związane z szachrajstwem są immanentną częścią fabuł; problem w odniesieniu do historiografii Królestwa Franków analizuje (bardzo pobieżnie zresztą) H. Reimitz, History, s. 166-239; zob. też A. Gillett, Envoys and Political Communication in the Late Antique West, 411-533, Cambridge 2003, s. 268, 269, przyp. 221; G. Scheibelreiter, Fredegar-Chronist einer Epoche, w: The Medieval Chronicle. Proceedings of the 1 $^{\text {st }}$ International Conference on the Medieval Chronicle Driebergen/Utrecht 13-16 July 1996, red. E. Kooper, Amsterdam-Atlanta 1999, s. 251-259; C. Bornholdt, Engaging Moments. The Origins of Medieval Bridal-Quest Narrative, Berlin-New York 2005.

${ }^{80}$ Paweł Diakon, Historia Langobardorum, I, cap. 20, s. 59: „Numquid fugiunt Heroli mei?”.

${ }^{81}$ Tamże: „Non [...] hoc ego, sed tu rex ipse dixisti”. W. Goffart twierdzi, że słowa te przypominają motyw znany z Talmudu, a mianowicie komentarz do śmierci rabbiego Jehudy ha-Nassiego; zob. tenże, The Narrators of Barbarian History (A.D. 550-800): Jordanes, Gregory of Tours, Bede, and Paul the Deacon, Notre Dame 2005, s. 428, przyp. 318. Pierwszym, który zwrócił uwagę na podobieństwa między obiema opowieściami, był M. Gaster, Zur Quellenkunde deutscher Sagen und Märchen, „Germania”, 25, 1880, s. 274-294, zwł. s. 287. Krytyczne argumenty przeciw tej tezie przytoczył Th. Zachariae, Ihr sagt es, nicht ich!, „Zeitschrift des Vereins für Volkskunde”, 25, 1915, s. $402-408$ (na s. 403 fragment opowieści o śmierci owego rabbiego). Z kolei D. Shanzer krytycznie ustosunkowała się do twierdzenia W. Goffarta. Badaczka ta jednak twierdzi, że inspiracją dla tej opowieści może być Nowy Testament i rozmowa między Chrystusem a Piłatem, a szczególnie słowa: 'Tu es rex Judaeorum?' Dicit illi Iesus: 'Tu dicis'; zob. taż, Laughter and Humour in the Early Medieval Latin West, w: Humour, History and Politics in Late Antiquity and the Early Middle Ages, red. G. Halsall, Cambridge-New York 2002, s. 36-37.

82 J. Huizinga, Homo ludens. A Study of Play-element in Culture, London 1949, s. 81.

${ }^{83}$ Fredegar, Chronicae, IV, cap. 27, wyd. B. Krusch, MGH, Scriptores Rerum Merovingicarum, t. 2, Hannoverae 1888, s. 131 n. 
bratu, królowi Austrazji Teudebertowi II $^{84}$. Jednak wojsko nie chciało walczyć i leudes Teuderyka namawiali króla, aby rozpoczął z bratem, który stał ze swoją armią nieopodal, negocjacje pokojowe. Jedynym człowiekiem w armii Teuderyka, który chciał wojny, był oczywiście Protadius. Wojsko króla rozbiło obóz w twierdzy Cariatiacum w Neustrii. W obozie niezadowoleni leudes Teuderyka zaatakowali Protadiusa i wykrzyczeli do niego: „lepiej będzie, gdy jeden człowiek umrze, niż żeby całe wojsko znalazło się w niebezpieczeństwie" ${ }^{85}$. W tym samym czasie majordom siedział w królewskim namiocie, zabawiając się grą (tabula ludens) z głównym medykiem Piotrem. Wtem wojska Teuderyka otoczyły namiot. Król tymczasem, zatrzymany przez własnych ludzi, posłał jednego ze swoich zaufanych, Uncelena, z rozkazem powstrzymania wojowników przed zabiciem Protadiusa. Ten jednak nie wypełnił rozkazu swego króla. Uncelen - który odgrywa w tym miejscu rolę szachraja-przechery - ogłosił wojownikom: „Pan Teuderyk rozkazuje, aby zabić Protadiusa" ${ }^{" 86}$. Usłyszawszy te słowa, wojownicy z obnażonymi mieczami wpadli do namiotu i zabili majordoma. Zmieszany zajściem oraz przymuszony okolicznościami Teuderyk zawarł pokój z bratem i wojska powróciły do domów bez żadnych strat ${ }^{87}$.

To, czy dzieło Pseudo-Fredegara było znane Pawłowi Diakonowi jest kwestią sporną ${ }^{88}$. Niektórzy badacze uważają, że obaj dziejopisarze korzystali z tego samego, zaginionego dziś źródła, co tłumaczyłoby, dlaczego w obu dziełach znajdujemy podobne, niekiedy unikalne, informacje ${ }^{89}$. Inni sądzą, że Paweł Diakon korzystał z dzieła Pseudo-Fredegara ${ }^{90}$. Przyjmując tę ostatnią hipotezę, można byłoby twierdzić, że Paweł wzorował się na Pseudo-Fredegarze i gra Rodulfa jest luźno oparta na motywie zabawy Protadiusa przy stole w namiocie pod Cariatiacum. Odżegnując się jednak od tego typu rozważań spekulatywnych, skomentuję tylko w kilku słowach motyw szachraja w dziele longobardzkiego dziejopisa. Nie ustalono w gruncie rzeczy, który z „narratorów barbarzyńskiej historii” rozpoczął modę na wprowadzanie tricksterów do narracji ${ }^{91}$. Badacze twierdzą, że rolę trickstera w Historiae Grzegorza z Tours odgrywa momentami frankijski władca Chlodwig I, a więc Pseudo-Fredegar nie byłby pierwszym dziejopisem w regnum Francorum, u którego pojawia się taka postać92. Jest jednak pewne, że w królestwie Franków i w regnum Longobardów istniało zapotrzebowanie na opowieści, w których sprytny szachraj dzięki podstępowi umiał wyjść cało z najbardziej nawet karkołomnych sytuacji. Umyślny z opowieści

${ }^{84} \mathrm{Na}$ temat tych wydarzeń zob.: E. Ewig, Die Merowinger, s. 50-52; I. Wood, The Merovingian, s. 131 n.; B.S. Bachrach, Merovingian, s. 77.

${ }^{85}$ Fredegar, Chronicae, IV, cap. 27, s. 131: „melius esse uno hominem moriturum, quam totum exercitum in periculum mis sum”.

86 Tamże, s. 132: „Sic iobet domnus Theudericus, ut interficiatur Protadius”.

87 Zob. komentarze: H. Reimitz, History, s. 180.

${ }^{88}$ W kwestii, czy Paweł Diakon korzystał z longobardzkiej tradycji ustnej zob. D.A. Bullough, Ethnic History and the Carolingians. An Alternative Reading of Paul the Deacon's Historia Langobardorum, w: tenże, Carolingian Renewal. Sources and Heritage, Manchester-New York 1991, s. 104; zob. jednak komentarze: W. Pohl, Paulus Diaconus und die „Historia Langobardorum". Text und Tradition, w: Historiographie im frühen Mittelalter, red. A. Scharer, G. Scheibelreiter, Wien-München 1994, s. 385. Zwolennicy tzw. modelu etnogenezy są zdania, że ludy barbarzyńskie kultywowały tzw. plemienną pamięć (eine gentile memoria), która relacjonowała m.in. o czynach władców i dzielnych wojowników; zob. H. Wolfram, Die Goten, s. 26-27. Zauważmy tutaj tylko, że Paweł Diakon sam podkreśla, że niewiele wiadomo o czynach króla Arioalda, tenże, Historia Langobardorum, IV, cap. 41, s. 133 n. Problem warto rozważyć szerzej w innym miejscu. Fakt, że Paweł Diakon nie zdobył wielu informacji o Arioaldzie, Th. Mommsen łączył z tym, że autor zaginionego dziś dzieła, tzw. historiola, Secundus z Trydentu, zmarł w 612 r., a wiec kilkanaście lat przed panowaniem tego władcy. Owa historiola była głównym źródłem Historia Langobardorum; zob. T. Mommsen, Die Quellen, s. 507.

${ }^{89}$ Zob. A. Fischer, Rewriting History. Fredegar's Perspectives on the Mediterranean, w: Western Perspectives on the Mediterranean. Cultural Transfer in Late Antiquity and the Early Middle Ages, 400-800 AD, red. A. Fischer, I.N. Wood, London 2014, s. 55-76, zwł. s. 58.

90 Zob. G. Monod, rec. Pauli Historia Langobardorum, „Revue critique d'histoire et de littérature”, 7, 1879, s. 272-276, zwł. s. 276; W. Goffart, The Narrators, s. 384, przyp. 169 oraz s. 402.

91 Zob. D. Shanzer, Laughter, s. 36.

92 I. Wood, Iocundus in fabulis. The Value of Friendly Advice, w: Splendor Reginae. Passions, genre et famille. Mélanges en l'honneur de Régine Le Jan, Turnhout 2015, s. 329-339; M. Heinzelmann, Gregory of Tours. History and Society in the Sixth Century, Cambridge 2001, s. 18, przyp. 94; S. Esders, „Avenger of all Perjury” in Constantinople, Ravenna and Metz. St Polyeuctus, Sigibert I and the Division of Charibert's Kingdom in 568, w: Western Perspectives on the Mediterranean, s. 17-40, 111-129; H. Reimitz, History, s. 109, 111. 
o grze Rodulfa dzięki sprytnej sztuczce ratuje własną skórę i tak relacjonuje przebieg bitwy, że to nie on, lecz sam monarcha oznajmia, iż Herulowie uciekają z pola bitwy, a przecież to umyślnemu groziła śmierć, gdyby ogłosił swemu władcy, że niezwyciężona - jak dotąd - herulska armia znajduje się w odwrocie. Dzięki przemyślnemu wybiegowi trickster ratuje własne życie, a śmierć - która groziła mu, gdyby ogłosił swemu władcy klęskę Herulów - spada ostatecznie na jego króla.

U Pseudo-Fredegara również działania Uncelena, który wypacza rozkaz króla Teuderyka, mają za zadanie uratować od zguby niewinnych. W tym przypadku stawka jest wyższa, Uncelen ratuje nie tylko własną skórę, lecz dzięki jego wybiegowi ocalone zostaje życie wielu wojowników. Przeinaczony rozkaz królewski daje wojakom Teuderyka powód do rozprawienia się z Protadiusem i tym samym sprytna sztuczka szachraja doprowadza do śmierci tego, który jako jedyny w całej armii dążył do bratobójczej wojny. Przemyślny wybieg wciela w życie słowa „lepiej będzie, gdy jeden człowiek umrze, niż żeby całe wojsko znalazło się w niebezpieczeństwie".

Dwie relacje o klęsce Herulów w bitwie z Longobardami są opowieściami, które w iście wirtuozerski sposób wyjaśniają odbiorcom, że losy bitew, tudzież wojen, nie zależą od siły wojowników i militarnego prestiżu ludu. Przesłanie obu chrześcijańskich autorów jest całkiem inne. Na nic zdają się takie przymioty jak sława wojenna, przewaga liczebna i siła militarna, jeśli Bóg stoi po stronie sprawiedliwych lub wspiera tych, którzy nie kierują się butą. $\mathrm{O}$ wynikach starć na polach wczesnośredniowiecznych bitew - tak głosi przesłanie Prokopiusza z Cezarei i Pawła Diakona - decyduje wyrok Niebios.

\section{A few remarks on two stories about the Lombards victory over Heruls}

\section{(Paul the Deacon, Historia Langobardorum, 1:20, and Procopius of Caesarea, De Bellis, 6:14)}

Summary: The article presents an analysis of two narratives of the war between the Heruls and the Lombards fought in 508. Leaving aside any attempts to see "how it really was" with the course of the conflict, the author focuses on a narrative side of the story written by Procopius of Caesarea and Paul the Deacon. The accounts of both authors are subjected to one main idea: that the victory depended neither on the size and strength of the army, nor the courage of the troops, but was the result of God's decision to support one of the sides. In the version presented by Procopius, God in the form of a black cloud took side with the Lombards, who with a sense of profound humility wanted to avoid military conflict to the end, and were forced to go to war. The defeat of the Heruls was their punishment for initiating the war without any just reason. In the version presented by Paul the Deacon the defeat of the Heruls was the punishment for the arrogance of their king and the contempt this soldiers felt for the Lombardian troops.

Nota o Autorze: Robert Kasperski, adiunkt w Instytucie Historii im. Tadeusza Manteuffla Polskiej Akademii Nauk. Zainteresowania badawcze: historia wczesnego średniowiecza, historia historiografii, etnohistoria, narratywistyka oraz metodologia nauk humanistycznych.

Author: Robert Kasperski, assistant professor at the Tadeusz Manteuffel Institute of History, Polish Academy of Sciences. Research interests: history of the early Middle Ages, history of historiography, ethnohistory, narrativistics, and methodology of the humanities.

Instytut Historii PAN

ul. Rynek Starego Miasta 29/31

00-272 Warszawa

e-mail: robertkasperski@gmail.com 


\section{Bibliografia}

Balzaretti R., Sexuality in Late Lombard Italy, c. $700-$ c. 800 AD, w: Medieval Sexuality. A Casebook, red. A. Harper, C. Proctor, New York-Oxon 2007, s. 7-31

Banaszkiewicz J., „Nadzy wojownicy” - o średniowiecznych poglosach dawnego rytu wojskowego (Prokopiusz z Cezarei, Pawet Diakon, Girald z Walii, Sakso Gramatyk i Gall Anonim), w: tenże, Takie sobie średniowieczne bajeczki, wprow. M. Tomaszek, Kraków 2012, s. 361-389

Banaszkiewicz J., Rodulf, król Herulów, który grat (Pawet Diakon, Hist. Long., I, 20), w: E scientia et amicitia. Studia poświęcone profesorowi Edwardowi Potkowskiemu w sześćdziesięciopięciolecie urodzin i czterdziestolecie pracy naukowej, red. M. Drzewiecki, Warszawa-Pułtusk 1999, s. 23-31

Bianchi D., L'elemento epico nella „Historia Langobardorum”, „Memorie Storiche Forogivliesi”, 30, 1934, nr 1, s. $117-168$

Bullough D.A., Ethnic History and the Carolingians. An Alternative Reading of Paul the Deacon's Historia Langobardorum, w: tenże, Carolingian Renewal. Sources and Heritage, Manchester-New York 1991, s. 97-122

Frye N., Myth, Fiction, and Displacement, w: tenże, Fables of Identity. Studies in Poetic Mythology, New York 1963

Goffart W., Barbarian Tides. The Migration Age and the Later Roman Empire, Philadelphia 2006

Goffart W., Conspicuously Absent. Martial Heroism in the Histories of Gregory of Tours and its Likes, w: tenże, Barbarians, Maps, and Historiography. Studies on the Early Medieval West, Farnham-Burlington 2009, s. 95-120

Goffart W., The Narrators of Barbarian History (A.D. 550-800): Jordanes, Gregory of Tours, Bede, and Paul the Deacon, Notre Dame 2005

Gschwantler O., Formen langobardischer mündlicher Überlieferung, „Jahrbuch für internationale Germanistik”, 11, 1979, nr 1, s. 58-85

Halsall G., Warfare and Society in the Barbarian West, 450-900, London-New York 2003

Haubrichs W., Ehre und Konflikt. Zur intersubjektiven Konstitution der adligen Persönlichkeit im früheren Mittelalter, w: Spannungen und Konflikte menschlichen Zusammenlebens in der deutschen Literatur des Mittelalters. Bristoler Colloquium 1993, red. K. Gärtner, I. Kasten, F. Shaw, Tübingen 1996, s. 35-58

Haubrichs W., Die 'Erzählung des Helden' in narrativen Passagen der Historia Langobardorum des Paulus Diaconus, w: Narration and Hero. Recounting the Deeds of Heroes in Literature and Art of the Early Medieval Period, red. V. Millet, H. Sahm, Berlin-Boston 2014, s. 278-304

McKitterick R., Paul the Deacon's Historia Langobardorum and the Franks, w: taż, History and Memory in the Carolingian World, Cambridge-New York 2004, s. 60-83

Miller D.A., The Epic Hero, Baltimore-London 2000

Nelson J.L., Bad Kingship in the Earlier Middle Ages, „Haskins Society Journal”, 8, 1999, s. 1-26

Reimitz H., History, Frankish Identity and the Framing of Western Ethnicity, 550-850, Cambridge 2015

Rubin B., Das Zeitalter Iustinians, t. 1, Berlin 1960; t. 2, Berlin-New York 1995

Shanzer D., Laughter and Humour in the Early Medieval Latin West, w: Humour, History and Politics in Late Antiquity and the Early Middle Ages, red. G. Halsall, Cambridge-New York 2002, s. 25-47

Wallace-Hadrill J.M., Gregory of Tours and Bede. Their Views on the Personal Qualities of Kings, „Frühmittelalterliche Studien", 2, 1968, s. 31-44

Wallace-Hadrill J.M., War and Peace in the Earlier Middle Ages, „Transactions of the Royal Historical Society”, 25,1975 , s. $157-174$

Wood I., Iocundus in fabulis. The Value of Friendly Advice, w: Splendor Reginae. Passions, genre et famille. Mélanges en l'honneur de Régine Le Jan, Turnhout 2015, s. 329-339

Wyatt D.R., Slaves and Warriors in Medieval Britain and Ireland, 800-1200, Leiden-Boston 2009

Wynn Ph., Wars and Warriors in Gregory of Tours' Histories I-IV, „Francia”, 21, 2001, nr 1, s. 1-35

Żmudzki P., Władca i wojownicy. Narracje o wodzach, drużynie $i$ wojnach w najdawniejszej historiografii Polski $i$ Rusi, Wrocław 2009 